\title{
Analiza perspektyw rozwoju bitcoina w kontekście możliwości pełnienia funkcji pieniądza*
}

\author{
Autorzy: Marzena Franków, Tomasz Kopyściański
}

\begin{abstract}
Abstrakt
Zagadnienie funkcjonowania kryptowalut stanowi zupełnie nowy problem naukowy, nie tylko w wymiarze krajowym, ale również międzynarodowym. W aktualnym dorobku literatury przedmiotu, zarówno z dziedzin nauk prawnych, jak i ekonomicznych, brakuje publikacji wyjaśniających istotę oraz mechanizmy funkcjonowania elektronicznych środków płatniczych opartych o rozwiązania kryptograficzne. Tymczasem rozwój cywilizacji, a zwłaszcza budowany w oparciu o nowe technologie rozwój wirtualnych społeczności generuje nowe formy transakcji oraz sposób ich rozliczania, które wychodzą dalece poza zakres obecnego stanu wiedzy oraz istniejących rozwiązań prawnych. Przyczyn pojawienia się kryptowalut upatruje się nie tylko w niedostatkach tradycyjnego systemu walutowego, który nie potrafił stawić czoła licznym kryzysom, ale także w szybkim rozwoju Internetu, dla którego kryptowaluty mogą być bardziej dostosowaną formą pieniądza. Kryptowaluty budzą jednakże wiele kontrowersji prawnych, przez co ich użytkownicy są narażeni na istotne ryzyko prawne oraz ekonomiczne.

W związku z tym przedmiotem badań w ramach niniejszego artykułu jest analiza ekonomicznej istoty bitcoina jako najbardziej rozpowszechnionej obecnie kryptowaluty. Zasadniczym celem w tym zakresie jest ocena roli bitcoina w zakresie możliwości pełnienia funkcji pieniądza.
\end{abstract}

Słowa kluczowe: pieniądz, funkcje pieniądza, kryptowaluty

JEL: E42, E43

\section{Wstęp}

Rozwój technologiczny i postępująca informatyzacja społeczeństwa stanowią podatny grunt do poszukiwania nowych sposobów nawiązywania
Historia: otrzymano 2016-04-07, poprawiono 2016-04-07, zaakceptowano 2016-06-02

stosunków ekonomicznych. W ostatnim czasie szczególnie interesującym zjawiskiem w tym zakresie jest powstanie i rozwój kryptowalut jako nowej formy dokonywania i rozliczania transakcji. Oryginalność zastosowanych

\footnotetext{
* Publikacja powstała $w$ ramach projektu, który został sfinansowany ze środków Narodowego Centrum Nauki przyznanych na podstawie decyzji nr DEC-2013/09/B/ HS5/00019
} 
rozwiązań, zarówno pod względem technologicznym, jak i ekonomicznym, istotnie odróżnia kryptowaluty od tradycyjnych, dotychczas wykorzystywanych rozwiązań w obszarze realizacji płatności. Najbardziej znanym i rozpowszechnionym w obrocie gospodarczym przykładem kryptowaluty jest bitcoin. Wzrost znaczenia tej kryptowaluty w zakresie dokonywania płatności stawia pytania nie tylko o rolę kryptowalut w aspekcie ekonomicznym, ale również o możliwości przejęcia w gospodarce roli przypisywanej obecnie wyłącznie środkom płatniczym oficjalnie uznawanym przez poszczególne państwa.

Głównym celem artykułu jest ocena bitcoina w zakresie potencjału pełnienia przezeń funkcji pieniądza. W ramach artykułu, na bazie rozważań teoretycznych odnoszących się do idei bitcoina w porównaniu do form współczesnego pieniądza, przedstawione zostaną wyniki badań empirycznych zmierzające do sformułowania wniosków na temat perspektyw rozwoju bitcoina i ewentualnego potencjału pod względem możliwości konkurowania z tradycyjnymi walutami.

\section{Pojęcie i istota bitcoina}

Problematyka związana z ekonomicznymi implikacjami wynikającymi z funkcjonowania bitcoina w obrocie gospodarczym nie została jak dotychczas obszernie opisana w literaturze przedmiotu. Najczęściej zagadnienie opisywane jest z perspektywy technologicznej wyjaśniającej sam mechanizm tworzenia kryptowaluty. Bitcoin (BTC) został po raz pierwszy zaprezentowany w 2008 r. przez osobę bądź grupę osób działających pod pseudonimem Satoshi Nakamoto. Przedstawiona wówczas koncepcja wyjaśniała system tworzenia oraz sposób funkcjonowania jednostek BTC, zarówno na gruncie ekonomicznym, jak i socjologicznym. Podłoże socjologiczne stanowiło jeden z istotnych elementów budujących fenomen zjawiska, jakim są kryptowaluty, przyciągającym do jego korzystania osoby ideowo odrywające się od głównego nurtu ekonomii i wyrażające niezadowolenie społeczne z obecnych zasad funkcjonowania gospodarki. Podstawę odzwierciedlenia $w$ systemie płatniczym idei bezpieczeństwa i wolności miały stanowić specyficzne, komplementarne rozwiązania wykorzystane przy jego konstrukcji.

Zgodnie z podstawowym założeniem bitcoin miał stanowić zdecentralizowany system elektronicznych płatności za pomocą sieci peer-to-peer, aby umożliwić dokonywanie transakcji między stronami, opierając się na wzajemnym zaufaniu. Wobec tego sieć jest tworzona przez samych użytkowników - ani bank, ani oficjalna procedura płatnicza nie jest obecna między użytkownikami BTC (Chrabonszczewska 2013: 55). Podaż waluty jest zwiększana dzięki tzw. górnikom (ang. miners). Na komputerach górników działa program poszukujący rozwiązań funkcji matematycznej, na której opiera się algorytm funkcjonowania protokołu bitcoin. Po znalezieniu rozwiązania wygenerowany zostaje blok, który zawiera transakcje na bitcoinach od momentu wykopania poprzedniego bloku. Nad procesem wprowadzania bitcoina do obiegu i wykorzystania w obrocie gospodarczym brak jest nadzoru organów państwowych, co w konsekwencji sugeruje całkowitą niezależność od rządów i instytucji finansowych. Ponieważ funkcjonowanie bitcoina oparte jest o zasady kryptografii, to źródłem zaufania jest w decydującej mierze dowód kryptograficzny. Efekt ten wspomagany jest wykorzystaniem aplikacji open source, co ma zapewniać jawność procesu powstawania kryptowaluty. Pomimo tego zachowana zostaje anonimowość użytkowników, co związane jest z faktem, iż przy założeniu konta (w sensie 
portfela, na którym gromadzone są bitcoiny) żadne informacje osobiste nie są wymagane i nie wymagają identyfikacji.

Z ekonomicznego punktu widzenia istotnym zagadnieniem jest ograniczona podaż bitcoina. Maksymalna liczba jednostek, które mogą być wprowadzone do obiegu, jest ograniczona z góry przez algorytm i nie przekroczy 21 milionów sztuk. Biorąc pod uwagę obecne tempo wzrostu mocy obliczeniowej sieci, prognozuje się, że wielkość ta zostanie osiągnięta około 2110 r. Naturalnie stała podaż jednostek, które zostaną wyemitowane do systemu, powoduje presję deflacyjną, jakiej poddany jest bitcoin. Ze względu na konstrukcję systemu żadna osoba ani organizacja nie ma możliwości zwiększenia ilości bitmonet, jakie będą funkcjonować w systemie. Ograniczona podaż przy zakładanym wzrastającym popycie ma prowadzić do systematycznego wzrostu wartości bitcoina. Aby zapobiec sytuacji utraty płynności, projektanci systemu zdecydowali, że 1 BTC dzieli się na $100 \mathrm{mln}$ mniejszych jednostek nazywanych zwyczajowo satoshi (Dopierała, Borodo 2014: 3).

Z uwagi na międzynarodowy oraz anonimowy charakter bitcoina liczba osób korzystających z tej kryptowaluty jest bardzo trudna do oszacowania (Piotrowska: 372). Brakuje oficjalnych danych na temat globalnej liczby użytkowników bitcoina. Ich liczbę można próbować określić na podstawie czynnych adresów bitcoin oraz statystyk publikowanych na stronach internetowych agregujących informacje na temat obrotu kryptowalutami. Podstawowe statystyki dotyczące bitcoina na przestrzeni badanych lat prezentuje tabela.

W początkowej fazie zainteresowanie bitcoinem było relatywnie niewielkie. Mała liczba użytkowników oraz ilość dokonywanych transakcji sprawiała, że zasięg oddziaływania ograniczony był do wąskiego grona pasjonatów nowych technologii i innowacji finansowych. Tym niemniej, już w początkowym okresie bitcoin był wykorzystywany jako środek wymiany, chociaż w dużej mierze do przeprowadzania transakcji w szarej strefie czy też wręcz nielegalnych. Dynamiczny rozwój bitcoina zapoczątkowany został w 2013 r. W roku tym skumulowana liczba pobrań klienta bitcoin wzrosła z 1,9 mln do ponad 4,2 $\mathrm{mln}$. Na fali popularności zjawiska oraz w dużej mierze dzięki temu, że oprogramowanie bazowego protokołu bitcoina udostępniane jest na wolnych licencjach, bardzo szybko powstawać zaczęły alternatywne monety - tak zwane altcoins. To sprawia, że obecnie w obrocie funkcjonuje równolegle już kilkaset różnych kryptowalut i cały czas powstają nowe. Nie zmienia to jednak na razie faktu, iż bitcoin pozostaje wciąż najbardziej znaną kryptowalutą, dlatego

Tabela 1. Podstawowe dane na temat bitcoina w latach 2010-2015 (stany na koniec roku)

\begin{tabular}{|c|c|c|c|c|c|c|}
\hline Wyszczególnienie & $\mathbf{2 0 1 0}$ & $\mathbf{2 0 1 1}$ & $\mathbf{2 0 1 2}$ & $\mathbf{2 0 1 3}$ & $\mathbf{2 0 1 4}$ & $\mathbf{2 0 1 5}$ \\
\hline $\begin{array}{c}\text { Liczba jednostek w obiegu } \\
\text { (w tys. jednostek) }\end{array}$ & 5051,5 & 8063,9 & 10621,2 & 12215,2 & 13674,7 & 15031,4 \\
\hline $\begin{array}{c}\text { Kapitalizacja } \\
\text { (w mln USD) }\end{array}$ & 1,5 & 35,9 & 142,3 & 9031,5 & 4241,3 & 6490,0 \\
\hline $\begin{array}{c}\text { Szacowana łączna liczba } \\
\text { adresów bitcoin } \\
\text { (w tys.) }\end{array}$ & 24,2 & 947,3 & 1908,7 & 4202,5 & 5534,7 & 7242,3 \\
\hline
\end{tabular}

Źródło: opracowanie własne na podstawie danych https://bitinfocharts.com/. 
też z perspektywy jego specyfiki przeanalizowane zostaną $\mathrm{w}$ dalszej części artykułu kwestie związane z możliwością odgrywania roli pieniądza.

\section{Formy współczesnego pieniądza i jego funkcje}

Niezależnie od swej formy zewnętrznej i systemu gospodarczego, pieniądz postrzegany jest obecnie jako prawnie określony, powszechnie akceptowany środek płatniczy, który może wyrażać, przechowywać i akceptować wartości i którego wartość jest ściśle związana z realnym PKB (Schaal 1996: 26). Przyjęty pieniądz jest przy tym powszechnie uznawanym środkiem przenoszenia wartości w przestrzeni lub czasie (Oyrzanowski 1997: 122-123). Jest to równoznaczne stwierdzeniu, iż pieniądz ma szereg właściwości i spełnia równolegle więcej niż jedną funkcję. Wymienia się w tym zakresie zwykle funkcje:

1) środka wymiany (cyrkulacji) pieniądz odgrywa rolę pośrednika w wymianie, co pozwala na oderwanie transakcji kupna od transakcji sprzedaży, eliminując tym samym niedogodności związane z wymianą barterową (Noga 2012: 71-76);

2) miernika wartości - pieniądz stanowi podstawę wyobrażeń o wartości dóbr i usług, co przejawia się w określeniu ich ceny (Milewski, Kwiatkowski 2008: 339-340). Ponadto wykształcenie pieniądza umożliwiło dokonanie porównania dóbr względem ich wartości, jakże ułatwiając podejmowanie decyzji gospodarczych;

3) środka tezauryzacji - pieniądz jest środkiem gromadzenia bogactwa (przechowywania wartości), m.in. dlatego, że umożliwia sumowanie wartości poszczególnych składników posiadanego majątku (Schaal 1996: 23). Funkcja ta traci oczywiście na znaczeniu wraz z przebiegającym intensywnie rozwojem rynków finansowych;
4) środka płatniczego - pieniądz umożliwia regulację zobowiązań finansowych, w tym wobec państwowych instytucji (Noga 2012: 76).

Należy przy tym podkreślić, iż funkcje pieniądza nie mają rozłącznego charakteru. Jednocześnie $w$ literaturze utrwaliło się przekonanie, że niektóre z wymienionych funkcji, a konkretnie funkcje miernika wartości i środka wymiany są pierwotne wobec pozostałych (Pietrzak, Polański, Woźniak 2008: 57). Ponadto, jak pokazuje historia pieniądza, z czasem znaczenie jednych funkcji może ulec trwałej redukcji, podczas gdy inne przybierać będą na znaczeniu. Równocześnie, nie w każdych warunkach pieniądz spełnia wszystkie swe funkcje. Przykładem może być środowisko inflacyjne, w którym ograniczona zostaje możliwość pełnienia przez pieniądz roli narzędzia tezauryzacji oraz środka wyrażania wartości.

Opisane rozległe zastosowanie i wielość wymienionych funkcji były historycznie zmienne. Niemniej jednak przyjęło się poprzez funkcje definiować pieniądz. Różnym rodzajom pieniądza nie są bowiem wspólne jego własności (cechy). Nie wystarczy również powiedzieć, że pieniądzem nazywamy to, co jest zwykle ofiarowywane albo otrzymywane przy zakupie lub sprzedaży dóbr, usług i innych rzeczy (Galbraith 1976: 6). Jak wolno sądzić, jest to nadmierne uproszczenie. Podstawowy podział wyróżnia postaci (formy, a nawet tworzywa) pieniądza - jest to ujęcie chronologiczne - i jest niemal tożsamy z podziałem na pieniądz posiadający wartość wewnętrzną (towarowy, pełnowartościowy) oraz fiducjarny (symboliczny, niepełnowartościowy). Rozwój form pieniądza obejmował pieniądz prymitywny, kruszcowy papierowy, bankowy, elektroniczny (Piaszczyński 2004: 19). Pojawienie się, rozwój oraz zanik wymienionych postaci pieniądza przebiegały niejednakowo w przestrzeni 
i czasie. Jednakże niejednokrotnie wyznaczały one nową jakość efektywności gospodarczej.

Współcześnie pieniądz występuje w dwóch formach:

- pieniądz gotówkowy (realny), występujący w formie materialnej pieniądza papierowego (banknoty) lub w postaci monet, emitowany przez władze monetarne danego państwa,

- pieniądz bezgotówkowy, niemający materialnej postaci fizycznej, który stanowi przedmiot ewidencji księgowej banków, kreowany w systemie bankowym poprzez kredyt. Naturalnie występowanie pieniądza w obecnych formach nie wyklucza w żaden sposób pojawiania się nowych środków płatniczych, które ewolucyjnie mogą zastępować, konkurować lub nawet wypierać aktualnie przyjęte formy. $Z$ tej perspektywy kryptowaluty mogą wyłaniać się jako alternatywa i to nie tylko dla pieniądza gotówkowego, ale również dla formy bezgotówkowej kreowanej w systemie bankowym. Niewątpliwie jednak, podobnie jak to miało miejsce $w$ historii ekonomii, możliwość pełnienia przez pieniądz wskazanych funkcji jest naturalną konsekwencją wyróżniania się przez niego szeregiem właściwości. Należą do nich przede wszystkim (Mishkin 2002: 87):

1. Cechy o charakterze sine qua non (warunek konieczny):

- rzadkość w sensie ekonomicznym - pieniądz powinien być dobrem o ograniczonej dostępności (podaży) w stosunku do występujących na rynku dóbr i usług,

- podzielność - pieniądz musi być podzielny na mniejsze jednostki bez straty na wartości, umożliwiając dokonanie zakupu towarów, których wartość jest relatywnie niska, a zarazem wyrażona bardzo dokładnie,

- przenośność - pieniądz powinien umożliwiać przenoszenie znacznych jego wartości, koncentrując wysoką wartość w niewielkiej objętości i wadze,

- trwałość - powinien wykazywać odporność na procesy starzenia, fizyczne zniszczenie, gwarantując przechowanie wartości,

- jednorodność - poszczególne jednostki pieniądza powinny być do siebie podobne,

- oryginalność - pieniądz powinien być trudny do podrobienia.

- Cechy o charakterze uzupełniającym (tzn. cechy, które nie są niezbędne, ale niewątpliwie ułatwiały w przeszłości lub obecnie pełnienie funkcji pieniądza, będąc źródłem zaufania do określonej jego formy, a zatem i przesłanką do jego powszechnej akceptowalności):

- wartość wewnętrzna - wynikająca z podwójnej użyteczności danego dobra, a więc możliwości gospodarczego wykorzystania w sposób inny niż użycie $w$ procesie wymiany,

- gwarancja emitenta - emitent (najczęściej jest nim państwo) jest gwarantem autentyczności znaków pieniężnych oraz ich honorowania przez uczestników obrotu gospodarczego i we wszelkich transakcjach.

Warto zwrócić szczególną uwagę, że opisane powyżej cechy w zróżnicowanym stopniu wpływają na możliwość pełnienia przez środek funkcji pieniądza. I tak, dla przykładu, cecha rzadkości jest kluczowa dla zdolności pełnienia funkcji tezauryzacji, z uwagi na to, że ograniczony dostęp z natury rzeczy jest czynnikiem zwiększającym prawdopodobieństwo rynkowego wzrostu lub przynajmniej przechowania siły nabywczej w czasie. Z drugiej strony, cechy podzielności oraz przenośności, w każdym razie intensywność ich występowania dla danego dobra stanowią przesłankę dla zdolności pełnienia funkcji środka wymiany (płatniczego). 
Bitcoin odznacza się większością wymienionych cech, a nierzadko w stopniu wyższym niż to miało miejsce w przypadku historycznych i współczesnych form pieniądza. Możemy zatem mówić o rzadkości, podzielności, przenośności (poręczności), trwałości, jednorodności oraz oryginalności bitcoina.

Rzadkość pieniądza utożsamiana jest zwyczajowo ze stopniem ograniczenia podaży pieniądza określonego rodzaju. W przypadku systemu Bitcoin jest to ustalony odgórnie, a zatem równolegle wpisany $w$ algorytm limit jednostek, które mogą zostać wygenerowane w przyszłości. Architektura systemu sprawia, iż z ograniczeniem podaży bitcoina jest ściśle związana możliwość dalszego ich podziału na mniejsze jednostki wartościowe - są to tzw. satoshi, których relacja w stosunku do jednostki obrachunkowej przedstawia się następująco: 1 BTC = 100000000 satoshi. Jak widzimy, jest to podzielność aż do ośmiu miejsc po przecinku, podczas gdy tradycyjne kwotowania walut wyliczane są do czterech miejsc po przecinku, a pieniądza gotówkowego - jedynie do dwóch, co może stanowić istotne ułatwienie posługiwania się bitcoinem w sytuacji potencjalnej aprecjacji kryptowaluty w konsekwencji utrzymującej się nadwyżki popytu nad podażą waluty.

Poręczność i jednorodność, uzyskiwane przez cyfrowy charakter, jak i oryginalność zapewniana poprzez zabezpieczenia kryptograficzne, również stanowią kwestię bezdyskusyjną. Nieco bardziej kontrowersyjne może być postrzeganie kwestii trwałości, z uwagi na czynnik ryzyka, jakim jest stabilność i bezpieczeństwo funkcjonowania systemów komputerowych i sieci internetowej. Tym niemniej, w porównaniu do pieniądza bezgotówkowego, kryptowaluty charakteryzują się bez wątpienia przynajmniej niemniejszą trwałością (wszak w ramach kreacji pieniądza w systemie bankowym pojawiają się analogiczne uwarunkowania technologiczne i związane $z$ tym czynniki ryzyka), a w porównaniu do pieniądza gotówkowego - nawet zdecydowanie większą.

Wyróżnianie się przez kryptowalutę opisanymi cechami jest bez wątpienia następstwem sposobu generowania jednostek oraz pozostałych aspektów funkcjonowania omawianej kryptowaluty. Uwarunkowania te wykluczają jednakże, zarówno obecnie, jak i w przyszłości, posiadanie przez kryptowalutę wartości wewnętrznej czy gwarancji emitenta.

\section{Analiza rozwoju kryptowaluty bitcoin z wykorzystaniem wybranych narzędzi statystycznych}

Analizie poddano szeregi dziennych logarytmicznych stóp zwrotu cen bitcoina wyrażonych w walutach: EUR, PLN, USD, JPY. Następnie dokonano zestawienia jej rezultatów z wynikami uzyskanymi dla dobranych analogicznie szeregów czasowych par walutowych tradycyjnych (EUR/USD, EUR/PLN, USD/PLN), instrumentów finansowych (w postaci indeksów S\&P index, WIG) oraz surowców (cen złota XAU/USD, cen ropy SC.F/USD) wywodzących się z tradycyjnych rynków. Podstawowe charakterystyki omawianych szeregów czasowych wyliczono dla zbioru 1418 obserwacji zawierających się w okresie od początku funkcjonowania kryptowaluty, tj. od lipca 2010 r. do grudnia roku 2015.

W ramach przeprowadzonych badań zastosowano podejście klasyczne, utożsamiając oczekiwaną stopę zwrotu $z$ dochodem oraz odchylenie standardowe stóp zwrotu - z ryzykiem (definiowanym jako zmienność). Wyższemu ryzyku, w tym przypadku interpretowanemu jako możliwość uzyskania stopy zwrotu innej niż oczekiwana, towarzyszy zwykle większy dochód. Jak wynika $z$ rysunku 1 , dostrzegalna jest realizacja tej zależności w przypadku 


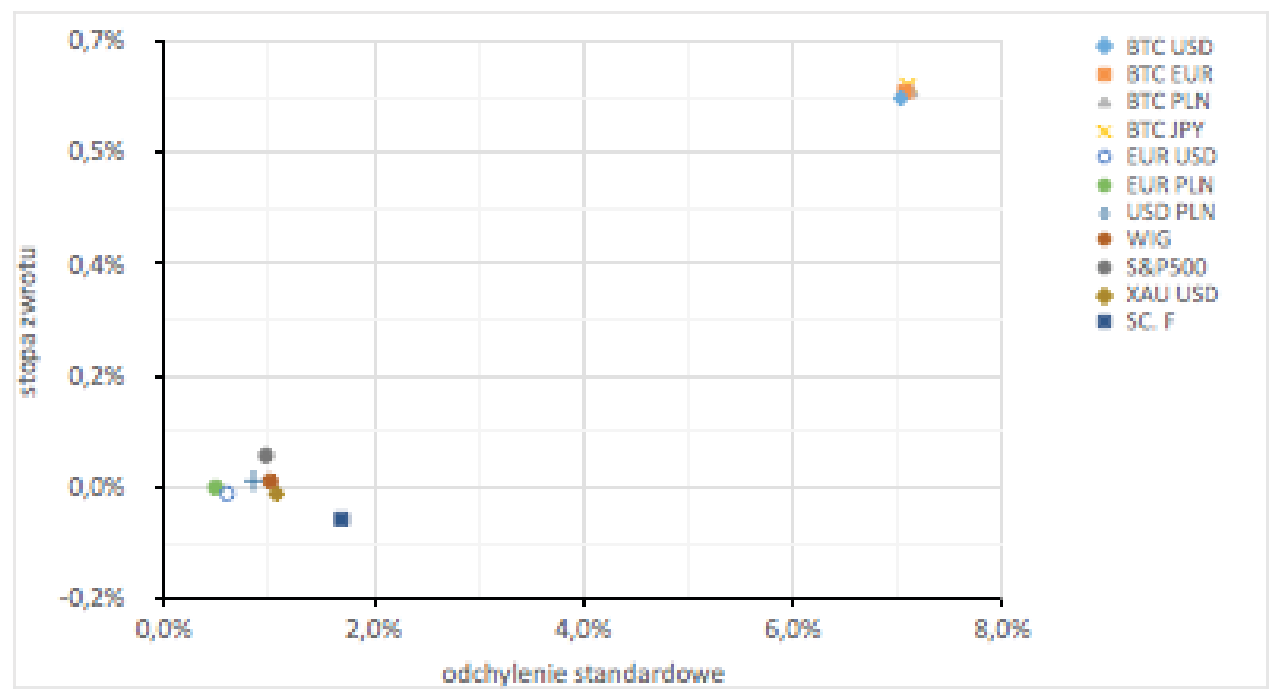

Rysunek 1. Wykres dochód-ryzyko 20.07.2010-31.12.2015

Źródło: opracowanie własne na podstawie danych https://bitinfocharts.com/.

BTC, bowiem wyznaczone wartości miar, zarówno średniej dziennej stopy zwrotu, jak i odchylenia standardowego, są niewątpliwie najwyższe (wynosząc odpowiednio ok. $0,6 \%$ oraz $7 \%$ ) w przypadku zmian cen bitcoina, niezależnie od rodzaju waluty kwotowanej. Wystarczy powiedzieć, że oczekiwane stopy zwrotu z uwzględnionych w badaniu tradycyjnych instrumentów finansowych są bliskie 0\%, natomiast wartości dziennego odchylenia standardowego rzadko przekraczają poziom $1 \%$.

Rozkład dziennych logarytmicznych stóp zwrotu BTC w okresie 20.07.2010-31.12.2015 przedstawiono na rysunku 2, z którego wynika, że $50 \%$ obserwacji zawartych jest pomiędzy pierwszym kwartylem wynoszącym -1,56\% a kwartylem trzecim wynoszącym 2,65\%. Uwagę zwraca wysoka wartość rozstępu (ok. 99 pp), co sugeruje, że zakres wahań cen bitcoina jest nieporównanie wyższy niż ten dostrzegany w przypadku tradycyjnych walut.

Zidentyfikowana zmienność oraz jej rozmiary wynikają m.in. z płytkości rynku kryptowaluty, która jest rezultatem realizowania relatywnie niskich obrotów na tym rynku. Jednakże rozstrzygającym elementem przyczyniającym się do utrzymywania się wysokiej zmienności bitcoina może być, eksponowana przez twórcę systemu, niezależność od państwowych organów nadzorujących. Tym samym wykluczone zostają zastosowania mechanizmów ograniczania wahań kursowych oraz zapobiegania spekulacjom walutowym (interwencje walutowe i inne instrumenty polityki pieniężnej). Stąd kurs bitcoina ustalany jest jedynie jako wynik relacji zachodzących między siłami rynkowymi na platformach wymiany.

Nadmierna zmienność notowań bitcoina może skutkować istotnym ograniczeniem zaufania użytkowników 


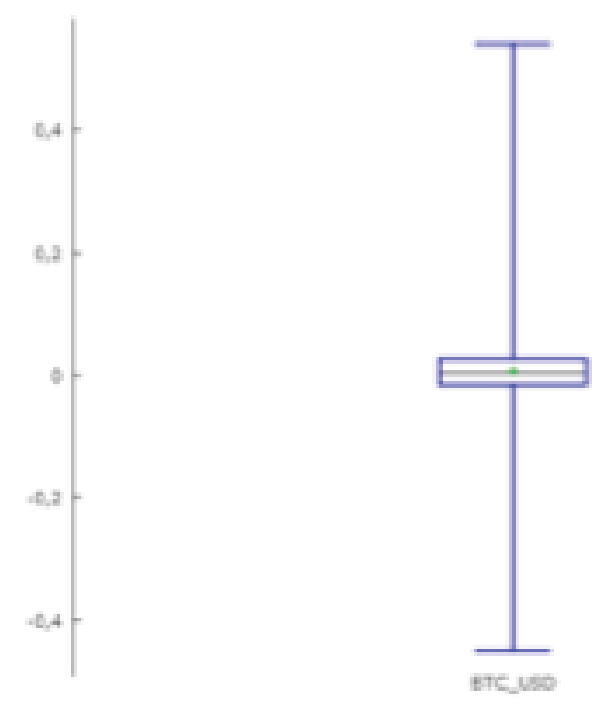

Rysunek 2. Rozkład dziennych logarytmicznych stóp zwrotu BTC/USD

Źródło: opracowanie własne na podstawie danych https://bitinfocharts.com/.

do posługiwania się tym środkiem płatniczym. Dotyczy to takich kwestii, jak możliwość występowania kryptowaluty w roli środka wymiany (cyrkulacji) czy regulacji zobowiązań (w szczególności w średnio- i długookresowej perspektywie), a nawet środka tezauryzacji. Dzieje się tak, ponieważ nie jest spełniony warunek stabilności siły nabywczej potencjalnego pieniądza.

\section{Ocena możliwości pełnienia przez bitcoin funkcji pieniądza}

Zgodnie z najbardziej rozpowszechnioną $w$ literaturze przedmiotu teorią funkcjonalną pieniądza, istota pieniądza określona jest przez spełniane przezeń funkcje, co pozwala przyjąć, że wszystkie środki, które spełniają funkcję pieniądza, należy definiować jako pieniądz (Schaal 1996: 23). Naturalnie uznanie danego środka za pieniądz jest sprawą dalece umowną $\mathrm{i}$ istotnie różni się $\mathrm{w}$ zależności od tego, czy przyjęty zostanie ekonomiczny czy też prawny punkt widzenia. W ujęciu ekonomicznym postrzeganie tego zagadnienia jest dość szerokie i elastyczne, a kwestią decydującą pozostaje powszechna akceptowalność - zjawisko o charakterze psychologicznym. Interesujące jest, że powszechne przyjmowanie danego środka jako zapłaty za dobra i usługi wynika z pewności (przekonania), że w danej gospodarce narodowej posiadanie pieniądza umożliwia zawsze nabycie towarów i usług o stałej wartości (Schaal 1996: 23). Niemniej jednak przyjęcie założenia o funkcjonalnej istocie pieniądza implikuje w pierwszej kolejności potrzebę rozważenia istoty kryptowalut ze względu na aktualną i potencjalną możliwość pełnienia funkcji miernika wartości, środka wymiany, środka płatniczego czy też środka tezauryzacji. 
Odnosząc się do rozważanych uprzednio zagadnień, funkcja miernika wartości identyfikowana jest jako możliwość określenia wartości towaru w formie pieniężnej w postaci ceny. $W$ takim rozumieniu kryptowaluty w swym ogólnym założeniu w sposób oczywisty spełniają podaną funkcję, wszak przy ich pomocy jest możliwe wyrażenie, a przez to i porównywanie wartości dóbr i usług funkcjonujących w obrocie gospodarczym. Można jednakże dywagować, czy nie jest to pozorne spełnianie funkcji miernika wartości. Wszak obecną wartość kryptowalut kształtuje, nie jak w przypadku tradycyjnych walut - jego siła nabywcza, lecz w dużej mierze kurs wymienny wobec walut tradycyjnych. Z pewnością natomiast trudno uznać, aby kryptowaluty spełniały obecnie powszechną funkcję miernika wartości w sensie możliwości określenia wartości wszystkich dóbr i usług będących przedmiotem transakcji rynkowych. W przypadku większości dóbr, z uwagi na ograniczone możliwości wymiany, kryptowaluty pełnią te funkcję co najwyżej pośrednio, właśnie za pośrednictwem tradycyjnych walut. Przykładowo cenę baryłki ropy naftowej na poziomie $50 \$$ za baryłkę można wyrazić jako 0,17 BTC (przy przyjętym umownie kursie przeliczeniowym 300\$/BTC), jednakże określenie wartości tego towaru następuje jedynie w wyniku przeliczenia kursu wymiany. Możliwość bezpośredniego określenia ceny wyrażonej w krytpowalucie jest bardzo ograniczona czy wręcz niemożliwa (wszak transakcje tym towarem nie są obecnie rozliczane w ten sposób, choć oczywiście potencjalnie mogą być w przyszłości). W rezultacie, choć $w$ ogólnym ujęciu kryptowaluty posiadają funkcję miernika wartości, to sposób jej realizacji, przynajmniej dotychczas, jest zbliżony bardziej do różnego rodzaju aktywów będących przedmiotem obrotu wtórnego (jak na przykład instrumentów finansowych na giełdzie), aniżeli do pieniądza w tradycyjnym ekonomicznym rozumieniu.

Z funkcją miernika wartości bardzo blisko związana jest kwestia odgrywania przez pieniądz roli środka wymiany. Właściwość ta związana jest z powszechną ekwiwalentnością środków pieniężnych w transakcjach kupna i sprzedaży towarów i usług. $W$ tej funkcji pieniądz staje się pośrednikiem w wymianie, co w ujęciu historycznym stanowiło możliwość odejścia od wymiany barterowej poprzez umowne „odrywanie” transakcji kupna od transakcji sprzedaży. Wymiana towaru na pieniądz stwarza tym samym możliwość podmiotowi sprzedającemu nabycie spełniającego jego potrzeby towaru lub usługi bez konieczności dokonywania bezpośredniej wymiany. Kryptowaluty również posiadają tę właściwość i jest to wśród omawianych funkcji ta, którą kryptowaluty spełniają bodaj w najintensywniejszym stopniu. Trudno jednak nie zaznaczyć faktu, że obecnie pełnienie tej funkcji nie ma jeszcze powszechnego charakteru, z uwagi na brak powszechnej akceptacji kryptowalut w zakresie dokonywania transakcji. Niemniej jednak, wraz z ewentualnym rozpowszechnieniem, zdolność potencjalnego zastosowania kryptowalut w zakresie funkcji wymiany nie stanowi kwestii szczególnie dyskusyjnej.

Rozwinięciem funkcji środka wymiany jest występowanie pieniądza w roli środka płatniczego, czego przejawem jest możliwość regulowania wszelkich zobowiązań finansowych, w tym w szczególności podatków, wynagrodzeń, zaciągania i spłat pożyczek (Noga 2012: 76). W tym przypadku kryptowaluty trudno uznać za środek realizujący wskazaną funkcję. W aktualnym, nieuregulowanym stanie uwarunkowań prawnych, przy braku równoległej akceptacji władz monetarnych państw w zakresie wykorzystywania kryptowalut możliwość regulowania zobowiązań, takich jak przede wszystkim 
podatki, jest automatycznie wykluczona. Można mieć przy tym poważne wątpliwości, na ile kryptowaluty ze względu na swoje cechy zawierają w sobie potencjał do pełnienia tej funkcji w dłuższej perspektywie czasowej. Wszak jedną z immanentnych cech kryptowaluty jest niezależność od rządów i innych organów władzy publicznej. Fakt ten powoduje naturalną sprzeczność, która ogranicza możliwość funkcjonowania tradycyjnego systemu finansowego w oparciu o kryptowaluty, a zwłaszcza tak kluczowego ogniwa jak system podatkowy. $W$ zasadzie upowszechnienie kryptowalut $\mathrm{w}$ roli pieniądza wiązałoby się z zupełną reorientacją stosunków ekonomicznych, w szczególności w zakresie obecnej roli państwa i organizacji systemu finansów publicznych.

Odrębną, interesującą kwestią jest możliwość pełnienia przez kryptowaluty funkcji środka tezauryzacji. Z jednej strony niematerialna postać kryptowaluty i będący tego konsekwencją brak wartości wewnętrznej z natury rzeczy ogranicza skłonność do przechowywania siły nabywczej w tej formie. Tym bardziej, że brak nadzoru i gwarancji państwa siłą rzeczy zwiększa niepewność co do bezpieczeństwa gromadzonych w ten sposób oszczędności. $Z$ drugiej jednak strony warto zauważyć, że w istotę tworzenia kryptowaluty nieodłącznie wpisany jest element tezauryzacyjny, czego głównym aspektem jest algorytm ograniczający ilość generowanych jednostek. Ograniczona podaż, wzmacniająca cechę rzadkości, zgodnie z mechanizmem rynkowym może stanowić czynnik sprzyjający aprecjacji kryptowaluty w dłuższej perspektywie. To może zatem zwiększać skłonność do posiadania kryptowaluty w celu przechowywania wartości. Słabością kryptowalut w zakresie funkcji tezauryzacyjnej może być jednak brak innego zastosowania niż cele rozliczeniowo płatnicze (w przeciwieństwie do $\mathrm{np}$. złota czy innych towarów1). Ponadto czynnikiem warunkującym skłonność do gromadzenia oszczędności $w$ tej formie jest niewątpliwe stabilność siły nabywczej pieniądza. Pieniądz realizuje funkcję tezauryzacyjną wówczas, gdy jako nabywcy ufamy, że przechowuje on wartość. Jednakże możliwość utrzymania stałej siły nabywczej przez kryptowalutę, jak wielokrotnie zostało to już przedstawione, jest w tym momencie dość mocno nieokreślona.

Należy podkreślić, iż wyodrębnienie zawartości znaczeniowej poszczególnych funkcji pieniądza jest nad wyraz umowne (Owsiak 2002: 108). Środki odgrywające rolę pieniądza spełniają wymienione funkcje jednocześnie, jak też realizacja jednej funkcji warunkuje spełnienie kolejnej. Przykładowo, dokonywanie transakcji (pieniądz jako środek wymiany) byłoby $w$ zasadzie niemożliwe $w$ oderwaniu od funkcji miernika wartości, identyfikującej ilość towarów, jaką można nabyć za jednostkę pieniężną, co zarazem stanowi warunek konieczny dla przeprowadzenia rozliczenia transakcji. Ponadto, aby pieniądz był środkiem tezauryzacji, niezbędne jest posiadanie przez niego siły nabywczej, nierozerwalnie związanej z możliwością zamiany pieniądza na określone dobra lub usługi mogące zaspokoić przyszłe potrzeby osób gromadzących oszczędności właśnie $w$ formie pieniężnej. Wzajemne zależności między spełnianymi funkcjami, mające $w$ tym wypadku komplementarny charakter, stanowią istotny element w dyskusji nad możliwością odgrywania

\footnotetext{
1 W przypadku złota, nawet gdyby hipotetycznie przestało być uznawane za drogocenne, wciąż pozostawałoby zastosowanie jubilerskie (choć ozdoby z niego wykonane nie byłyby już uznawane za prestiżowe (por. R. Faszyński, Jeśli bitcoin jest pieniądzem, to transferowym, http://www. obserwatorfinansowy.pl/tematyka/rynki-finansowe/jesli-bitcoin-jest-pieniadzem-to-transferowym/).
} 
przez krytpowaluty roli pieniądza. Współczesne formy pieniądza, zarówno gotówkowa, jak i bezgotówkowa, taką właściwość bez wątpienia posiadają. Tymczasem w przypadku kryptowalut, wprawdzie dostrzec można występowanie tych funkcji, lecz z różną intensywnością. Tym niemniej trudno, przynajmniej w obecnym stanie ich wykorzystania w obiegu gospodarczym, przyjąć wniosek, iż spełniają wszystkie podane funkcje w jednakowym stopniu czy też, że spełniane przez nie funkcje uzupełniają się wzajemnie. Dodatkowo pojawiają się poważne wątpliwości, w jakim stopniu i czy w ogóle kryptowaluty są w stanie pełnić niektóre funkcje, jak przede wszystkim funkcję środka płatniczego. To powoduje, że w ujęciu ekonomicznym kryptowalutom bliżej niż do pieniądza jest obecnie do instrumentu finansowego. Nie zmienia to jednak faktu, że z perspektywy rozwoju kryptowalut o ewentualnej możliwości zastosowania $\mathrm{w}$ roli powszechnego pieniądza zadecyduje jego akceptowalność i społeczne zaufanie. Jednakże wydaje się, że w tym względzie warunkiem koniecznym będzie stabilizacja siły nabywczej potencjalnego pieniądza.

\section{Podsumowanie}

Bitcoin, podobnie jak i inne kryptowaluty, obecnie nie jest oficjalnie

\section{Bibliografia}

Chrabonszczewska E. (2013), Bitcoin - nowa wirtualna globalna waluta? International Journal of Management and Economics, Warszawa, Wyd. Warsaw School of Economics.

Dopierała Ł., Borodo A. (2014), Znaczenie waluty kryptograficznej Bitcoin jako środka wymiany, Contemporary Economy, Vol. 5 Issue 2. uznawany przez poszczególne kraje, w tym Polskę, jako jednostka walutowa czy pieniądz elektroniczny. Fakt ten niewątpliwie ogranicza rozpowszechnienie bitcoina, powodując szereg utrudnień natury prawnej, jak i ekonomicznej. Nie zmienia to jednak faktu, iż bitcoin jest wykorzystywany przez użytkowników z różnych krajów, co automatycznie sprawia, że staje się siłą rzeczy niejako konkurencją dla oficjalnie uznawanych przez poszczególne państwa tradycyjnych walut.

Postrzegając rzecz w kategoriach futurystycznych, rozpowszechnienie bitcoina i wyparcie przezeń z obiegu tradycyjnych walut wiązałoby się z zupełnie nowym podejściem do pojęcia pieniądza i jego dotychczasowych funkcji. Z przeprowadzonych rozważań wyni$k a$, iż bitcoin nie jest sposobem na wyeliminowanie różnych rodzajów ryzyka w zakresie obrotu środkami pieniężnymi. Niestabilność kursu i ryzyka prawne związane z wykorzystaniem nowej waluty są trudne do uniknięcia. $Z$ drugiej strony nie można pominąć faktu, iż nowatorski charakter tworzenia kryptowalut, a także idea wykluczenia kontroli nad ich obrotem przez państwo zyskuje zwolenników, co należy odbierać nie tylko jako zjawisko społeczne, ale proces, który wraz z rozpowszechnieniem może wywoływać istotne skutki ekonomiczne.

Galbraith J.K. (1976), Money: Whence It Came, Where It Went, Boston.

Milewski R., Kwiatkowski E. (2008), Podstawy ekonomii, Warszawa, PWN.

Mishkin F.S. (2002), Ekonomika pieniądza, bankowości i rynków finansowych, Warszawa, PWN.

Noga M., (red.) (2012), Makroekonomia ze szczególnym uwzględnieniem 
polityki pieniężnej, CEDEWU, Warszawa.

Owsiak S. (2002), Podstawy nauki finansów, Warszawa, PWE.

Piaszczyński W. (2004), Anatomia pieniądza, Warszawa, SCRIPT.

Pietrzak B., Polański Z., Woźniak W. (2008), System finansowy w Polsce, PWN.
Piotrowska A. (2015), Czynniki oceny opłacalności inwestycji w kryptowalutę bitcoin, Zeszyty Naukowe Uniwersytetu Szczecińskiego nr 862, Finanse, Rynki Finansowe, Ubezpieczenia nr 75, Szczecin.

Schaal P. (1996), Pieniądz i polityka pieniężna, Warszawa, PWE.

\title{
Analysis of Bitcoin's Development Prospects in the Context of the Possibility of Performing Monetary Function
}

\begin{abstract}
Innovative technologies and the emergence of virtual communities create new types of transactions and the accounting methods that go beyond the current state of knowledge in economics and existing legal solutions. These virtual communities create and distribute their own medium of payment for the exchange of goods and services, thereby providing a means of payment in which emissions or circulation central monetary authorities are not involved. The reasons behind the emergence of cryptocurrencies are not only the shortcomings of the traditional currency system which was unable to face numerous crises, but also the development of the Internet for which cryptocurrencies can prove to be a better suited form of money. Unfortunately, they stir much legal controversy with the effect that their users are exposed to significant legal and economic risk.

Therefore, the subject of research presented in the article is to analyze the economic substance of Bitcoin. The main objective in this area is to assess the role of Bitcoin in terms of capacity to serve as money.
\end{abstract}

Keywords: money, monetary function, cryptocurrencies 